Humanistic Studies declares that the future citizen should possess knowledge, not only of the physical structure of the world, but also of "the deeper interests and problems of politics, thought, and human life," and that he needs "scientific method and a belief in knuwledge even more than physical science." This marks a change of attitude, and the advocates of the dominance of science in education would agree with the proviso that applications of science unknown to the ancients determine the conditions of health and of economic stability in modern life, and that a "belief in knowledge" and method in pursuing it are best inculcated by the study of law in the natural world.

The great merit of Sir Joseph Thomson's report is that it discloses the present causes of the weakness of science in our education. The universities as a whole now show a bias in favour of science teaching, but there is a deplorable lack of students, due partly to weakness in the schools, and partly to the influence of scholarship examinations in which classics predominate. Thus the old universities, by their scholarship systems, tend to discourage science teaching in the public schools, and the public schools react upon the preparatory srhools. It follows that many of the most intelligent boys are deterred from entering upon a scientific career. It is also possible that some class prejudice, based upon long tradition, dating back to the . Renaissance, may still operate against science training. The recommendations of the Committee are wise and far-reaching, but I can give only the barest indication of their objects and scope. Nature-study in primary schools up to the age of twelve is to be the foundation, and instruction in science up to the age of sixteen is enjoined upon all secondary schools, physics and chemistry to be taught, because all other sciences, to which they should be treated as passports, require some knowledge of them Mathematics should be connected with science at an early period. The general aims of a science course at school age are defined with the view of securing two educational objects of primary importance :- -

(I) To train the mind to reason about things the boy nbserves himself, and to develop powers of weighing and interpreting evidence.

(2) To develop acquaintance with broad scientific principles and their application in the lives of men and women.

No better foundation for the training alike of the statesman, the leader of commerce and industry, and the manual worker can be laid down. The Cummittee was strongly impressed with the importance of manual work at school-age, and, speaking from personal experience, I am certain that I owe much to the handling of the file and the lathe before I entered the Army, although mechanical pursuits at one time caust $\mathrm{d}$ me to neglect other studies. I believe that if all classes underwent some mamual training there would be a better understanding of the dignity of labour. Rightly distrusting examination tests of the conventional tvpe, the Committee recommends the inspection of all schools

Higher standards of teaching power, co-ordinated training from the primary school to the university and to the post-graduate stage, with a lowering of fees and a liberal allocation of scholarships to be awarded for "intellectual merit and promise," and not in accordance with the results of set examinations-such are the educational ideals which are set before the country. By these means we may hope in time to develop intelligence now wasted, as the Committee points out, to supply our present deficiency of experts in all branches of science, and to secure more orderly methods of administration and a higher average of leadership.

$$
\text { NO. 2539, VOL. IOI] }
$$

\section{SCIENTIFIC RESEARCH AND INDUSTRIAL} DEVELOPMENT. ${ }^{1}$

A $T$ the request of my friend, Lord Sydenham, I am pleased to support the work which has been so ably carried on by the British Science Guild, now under his leadership. I do so principally for two reasons: First, because of the importance of the work; secondly, because I believe that an erroneous impression exists in many quarters as to the attitude of the producing interests of this country to this work, and $I$ wish to endeavour to remove this impression.

'There has been, I fear, a tendency in certain. quarters to misjudge the attitude of manufacturers upon this subject. The impression seems to prevail that they are not fully alive to the necessity for research work in connection with their industries. This may be true in some quarters, but, speaking generally, I think there is no body of men more keenly alive to the necessity for a very great development in the application of science to industry.

Among employers there are comparatively few who have studied science or taken degrees in science before entering a business career, but the number of those who have done so has been steadily growing, and is certain to have a great influence upon the future of industry. Further, there is a large number, chiefly of the smaller manufacturers, who have grown up to the practice of "rule of thumb" methods, and will probably never depart from them.

There is, however, a- large number, and they are chiefly of the most enterprising and intelligent kind, who have a keen appreciation of what science has done, and may yet do, for their industries, and are alive to the necessity of employing men of scientific attainments, and of encouraging others to undergo a training in science. In my industry I believe there are very few firms which do not employ chemists for the purpose of their business. Mine has never been without them for many years, and has found the value of their services.

I think we cannot absolve Parliament from a share -and that a large one-of the responsibility for our deficiency in scientific research as compared with some other countries. Not only has it been most niggardly in the provision that it has made for the study of science: it has persistently ignored, time after time, the claims of business men for legislation that would enable the application of scientific discoveries to take place, and encourage the application of these discoveries for business purposes. The most familiar illustration of this is the trade in aniline dyes. I maintain that the blame for the unfortunate position of this industry at the beginning of the war rests chiefly upon Parliament. Many times the demand was made by the dye producers that alcohol should be allowed free of duty for dye-making; but requests were refused, and the advantage of free alcohol was enjoyed by the German producers, which rendered economic production here, in competition with them, impossible Further, year after year we went to the Board of Trade to give us a patent law that would be fair and reasonable, and not protect the foreigner and his inventions without reciprocal treatment in his country, but until Mr. Lloyd George became President in I9o6 nothing was done. These, in my opinion, are the two chief causes why the aniline dye trade was virtually lost to this country, and the blame for it rests upon the Government and upon Parlĩament, and not upon the business man.

The principle that trade must be left severely alone

1 From an address by Sir Algernon F. Firth, Bart., read at the annual meeting of the British Seience Guild held at the Mansion House on Jume 19 
and nothing be done to stimulate production at home, and that the only thing that counted was to buy in the cheapest market, prevailed here for far too long a period. This war has shattered our self-complacency in the application of this principle. People have learnt a great deal more about business and understand better what is in the national interest, and I hope a differen system is going to prevail in the future.

In order to give you evidence of the interest that commercial bodies are taking, and have taken, in this subject, I want to put before you a few facts. During the last six months of I915 I was chairman of the Sub-Committee appointed by the Board of Trade to take evidence from twelve minor industries which had afl been developed in this country in competition with former German supplies. This report was issued to Parliament and published in January, I916. The first recommendations that we made were:-."That the Committee thought that larger sums should be placed at the disposal of the new Committee of the Privy Council, and also with the Board of Education, for the promotion of scientific and industrial research and training.

"That the universities (the old universities as well as the new universities) sbould be encouraged to maintain and expand research work devoted to the needs of the main industry or industries located in their respective districts, and that the manufacturers engaged in those industries should be encouraged to co-operate with the universities in such work, either through their existing trade associations or through associations specially formed for the purpose. Such associations should bring to the knowledge of the universities the difficulties and needs of the industries, and give financial and other assistance in addition to that afforded by the city. . .

"In the case of non-localised industries they should be advised to seek, in respect of the centres of research, the guidance of the Advisory Council of the Committee of the Privy Council for Scientific Research:"

In the report we referred to svidence that was put before us to the effect that certain universities are taking up specific forms of research work. For instance, Sheffield University has taken up the subject of glass; at Stoke-on-Trent they are dealing with pottery-hard porcelain, china, and earthenware; and Manchester University is, I believe, equipping itself for studies. in connection with the paper trade. I believe that we have got to specialise in the different universities in research work which is interesting to the trade in their localities, and prevent a great deal of the overlapping which now exists.

We followed this up at a meeting of the Associated Chambers of Commerce, when more than five hundred delegates were present from all parts of the country. We considered the development of industry after the war, and passed unanimously this resolution:-

"That His Majesty's Government be urged to inquire into the desirability of fostering and safeguarding those industries in this country which have since the commencement of the war been engaged in the manufacture of articles formerly made, to a large extent, in enemy countries, or any industries which have in the past suffered seriously from German and Austrian competition; and further, for the development of industries generally, His Majesty's Government be urged to provide larger funds for the promotion of scientific research and training."

In June of the same year the Imperial Council of Commerce, representing the Chambers of Commerce of the whole Empire, held meetings in London and passed the following resolution:-"This conference urges that throughout the Empire larger funds shall be provided by the respective Governments in order that the fullest facilities may be given for the promotion of scientific research and training in their relation to our commercial and industrial development."

Before these meetings I went to Sir Alfred Keogh, the head of the Imperial College of Science and Technology in South Kensington, and suggested that, seeing these matters of applied science and scientific research were so prominently in men's minds in chambers of commerce, not only in Great Britain, but also throughout the Empire, he should arrange for the delegates to pay a visit to the Imperial College in order to enable them to realise what is actually being done there. He immediately agreed, and showed us such of the work as was possible in a two hours' visit, when we could have profitably spent two days informing ourselves of the activities of this magnificent college of science. 1 believe that out of those who went, only three had ever been there before. A fact that Sir Alfred Keogh stated to us made a great impression; it was that before the war there were only a thousand students at this college, and it could quite easily hold two thousand. We ought to be sending on students to a place like this from the whole country, so long as there is an opering for them. We should send them when they: Trave specialised in industrial subjects in order to broaden their minds and increase their knowledge. Sit Alfred stated:-"You will recognise, gentlemen, that the industries of this country are not fully alive to the importance of science, nor are the academies sufficiently aware of the importance of industries in the educational programme." This, we were bound 3 admit, was an accurate-statement of the position.

We are not the only nation that is taking steps in the direction of promoting scientific research. The United States are fully alive to the importance of the matter, and are keeping thoroughly posted on all steps taken here. My experienoe there-and it is a long one, being a manufacturer in America myselfis that men who are looking to be heads of businesses in the future spend far longer at universities and technical colleges before going to their business than we have been in the habit of doing in this country. We have undoubtedly been remiss in this respect, but I think that general sentiment is changing.

We must realise that scientific research is one of the most important questions that are coming before us in the industial reorganisation that will follow this war. We must all be impressed by this great factor: that business conditions are not going to be the same in this country or in the world when this great war is over. The war will have to be paid for, and.to do so the production of everything. agricultural as well as industrial, has got to be stimulated through all agencies and by improved methods generally. Labour will have to alter and relax all foolish and uneconomic restrictions on output, and I believe in most cases is prepared to do so; but at the same time employers will have to scrap antiquated methods. The have got to root out manv old prejudices, and must realise both the possibilities and responsibilities of their position. Our methods have been wasteful in the past; there will be no room for waste in the future. Everything must be turned to account and made the best use of. The old idea that business consists only of buying and selling to the best advantage, or in producing by known methods only. is exploded. A knowledge of world-markets and of opportunities must be more widely diffused and appreciated. Industrial organisation will probably exist in larger units, afford. ing greater opportunities for ability and the application of scientific knowledge. The attainment of the maximum production in industry should be the great object of

$$
\text { NO. } 2539 \text {, VOL. IOI] }
$$


us all. To secure this; scientific handling of materials and processes is necessary. Constant research, both on general and on particular or individual lines, is essential. This is becoming recognised by producers throughout the whole country.

For these reasons I consider that the British Science Guild has a great field for its activities, and if it continues: to press for the attainment of these objects I am sure that it deserves the cordial and hearty support of all who are interested in the safety and expansion of all those industries upon which the future of this nation so largely depends.

\section{UNIVERSITY AND EDUCATIONAL INTELLIGENCE.}

CAMBRIDGR.-Mr. C. R. A. Thacker, late scholar of Dowring College, has been elected to a fellowship at Sidney Sussex College. Mr. Thacker was placed in the first class of the Natural Sciences Tripos, part i., in xgIr, and part ii. (physiology) in 19I2. $\mathrm{He}$ is attached to the Special Medical Board of the Ministry of Pensions.

Leens.-Capt. M. J. Stewart has been elected professor of pathology and bacteriology in the University. He. received his commission in the R.A.M.C. (Territorial Force) in May, I915, and has served as pathologist to the East Leeds War Hospital, and in a similar capacity in France. A few months ago he was recalled to Leeds, and, at the request of the University Council, undertook the acting headship of the department of pathology and bacteriologv. In addition to his hospital and teaching work Capt. Stewart has devoted much time to original research on pathological questions; and has a long list of publications to his credit:

London.-The Senate announces a bequest of $2000 l$. for the engineering faculty of King's College under the will of Iieut. R. C. Hodson, a former student in the engineering department of the college, who was killed in France last year; also a donation of $5 \mathrm{Il}$. from Miss Gertrude Jones for the purposes of the Galton Laboratory at University College.

Grants haye been made by the Senate out of the Dixon Fund for the year rois-ig as follows :- Iool., $\mathrm{Mr}$. Birbal Sahni, to enable him to continue last year's research on Indian fossil plants at Cambridge; 6ol., $\mathrm{Mr}$. Tames Morrison, to enable him to continue research on the igneous rocks of the Lake District; Isl., Dr. H. B. Cronshaw, for expenses in connection with research on the Connemara serpentine rocks.

A resolution was adopted by the Senate on June in expressing gratification that the King's College Hospital had decided to open its medical school to women students-: "a step which is in entire conformity both with the wishes and the policy of the University."

The following doctorate has been conferred :-D.Sc. in Geology. Mr. A. E. Trueman, an external student, for a thesis entitled "The Evolution of the Iiparoceratide;" and other papers.

OxForn--The lately published report of the Delegates of the University Museum directs attention to the very large number of members of the teaching staff, research workers, and service staff of the museum and departments who are now serving in the Navy or Armv, or are otherwise engaged in worls directly connected with the war, $\Lambda$ large part of the museum is still occupied by the school of military aernnautics. A new dissecting-room for women medical students has been provided bv the liberality of the Clothworkers' Company, a deficit over the sum allotted being generously met bv Sir William Osler. Among the special investigations carried on NO. 2539 , VOL. IOI] in the several departments have been work on the agglutination curve in relation to yphoid and paratyphoid fevers, tetanus, "mustard gas," the commercial production of toluene from petroleum, the sulphonation of benzene and the manufacture of synthetic phenol, and the preparation of new chloroamides for use as antiseptics. A considerable amount of research work has also been pullished on subjects not directly connected with the war. The curator of the Pitt-Rivers Museum reports a very large accession of specimens by donation, chief among which are the examples presented by Lady Tylor from the collection of her late husband. Other important accessions have been received from Mr. J. H. Huton, Mrs. Braithwaite Batty, Mr. A. S. Kenyon, and : Major R. 'G. Gayer Anderson:

The How. Sir C. A. PARsons hats consented to fill the office of president of the Polytechnic School of Engineering, Regent Street, in succession to the late Mr. C. Hawksley.

We learn from a message from the Rome correspondent of the Times that the British Institute at Florence was formally opened on June 21 by Sir Rennell Rodd, Ambassador to the Court of Italy, who said that as Florence was the intellectual centre of Italv, the British Institute in Florence would provide facilities for the study of English by practical and scientific methods, the courses including classes in English history, geography, and literature. An attempt would also be made to explain and illustrate the chief problems of the British Empire. It was hoped that in the future the institute might become a point of contact between the principal British and Italian universities.

AT a series of conferences held during the present year representatives of the non-professorial teaching staffs of the universities and university colleges of England, Ireland, and Wales decided to take joint action for the purpose of securing an improvement in status, tenure, and salary. A memorandum has been prepared setting forth the present conditions of service and remuneration, which are admitted to be unsatisfactory by all conversant with the facts, and suggesting various remedies. Of these the most important is that the lecturing staff should be divided into three grades. The lowest grade would comprise appointments of a probationary character to last not more than three years. At the end of that time the junior lecturer or demonstrator should cease to hold the appointment. or, if it is desired to retain his services, he should be promoted to the next grade, that of lecturer on the permanent staff. The highhest grade would be composed of senior lecturers and lecturers in charge of departments. It is suggested as essential that there should be a definite minimum commencing salary in each grade, with substantial annual increments, and that lecturers should have a greater security of tenure, more time for study and research, and more adeauate representation on bodies that control the teaching in each university or college than prevail under existing arrangements. The memorandum is being presented to the governing bodies of each university or university college concerned. and there is reason to believe that the recommendations contained in it will receive favourable consideration. No improvement of salaries. however, can be expected without substantial aid from increased Treasury grants, and the promoters of the movement intend to make representations to the Government that such in creases of grant should be given as would make it brisible for governing bodies to meet the not unreasonable claims which have been put forward. 